UDC 66.011

\author{
R.I. Havryliv, V.V. Kochubei, I.V. Lutsyuk
}

\title{
KINETIC ANALYSIS OF THERMAL DECOMPOSITION OF FINELY DISPERSED LIMESTONE WASTES FOR THE DEVELOPMENT OF A NUMERICAL SIMULATION MODEL
}

\author{
Lviv Polytechnic National University, Lviv, Ukraine
}

\begin{abstract}
On the basis of the analysis of known literature data on $\mathrm{CaCO}_{3}$ thermal decomposition, it is concluded that the development of a compact engineering CFD model (computational fluid dynamics) for limestone calcination is a topical issue. This model can be based on thermogravimetric data and standard mathematical approximation algorithms. Experiments on thermal decomposition of finely dispersed limestone waste particles of different fractions less than $315 \mu \mathrm{m}$ were carried out using a Q-1500 D derivatograph (system F. Paulik, J. Paulik and L. Erdey) under non-isothermal conditions. Based on differential equations of topochemical solid-state kinetics and the asymmetry of differential thermogravimetry (DTG) curves, the values of activation energy, pre-exponential factor in Arrhenius equation were calculated and the reaction mechanism of the thermal decomposition of particles was determined from the results of non-isothermal experiments performed at the heating rate of $10^{\circ} \mathrm{C} / \mathrm{min}$ in a temperature range of 600 to $900^{\circ} \mathrm{C}$. A new engineering approach was developed to the CFD simulation of the thermal decomposition of limestone wastes by means of a two-step mechanism of solid-state kinetics using commercial CFD code ANSYS Fluent. The findings could be used in chemical engineering to produce new highly efficient equipment.
\end{abstract}

Keywords: activation energy, limestone wastes, thermal decomposition, topochemical reaction, reaction rate, CFD modeling.

DOI: $10.32434 / 0321-4095-2018-121-6-12-22$

\section{Introduction}

Nowadays, producing lime from finely dispersed limestone wastes is of considerable interest. The reason is that the finely dispersed limestone wastes are a key problem in lime production following the conventional technology in the shaft kilns. They are formed while preparing limestone for calcination. To solve this environmental problem, the cyclone type furnaces are advisable to be used.

The use of facilities of this sort is a highly efficient and economical method of chemical engineering for the thermal treatment of finely dispersed materials (production of cement, dolomite, limestone, alumina and other mineral products). Over recent years, numerical simulation methods based on computational fluid dynamics (CFD) modeling have been prevalently used to create cheap and effective cyclone-calciner furnaces or calciners optimize the design of these devices [1-3]. In addition, molecular modeling techniques are widely used to predict the structural properties of new materials in chemical engineering [4]. It should be noted that the correct CFD model of kinetics of the thermal decomposition determines the effectiveness of this approach.

The use of a simplified approach based on a 1step reaction rate mechanism is dominated in most computer simulation studies for industrial applications. According to this method, the rate that is constant for a chemical reaction is computed by using an expanded version of the Arrhenius expression. This requires the estimation of kinetic parameters of the thermal decomposition reaction (an activation energy, E and pre-exponential factor, A) to carry out the CFD modeling of chemical reactions. These parameters are rigidly related to the reaction mechanism.

In the last quarter-century, a series of studies have been performed in this direction. Different techniques of identifying kinetic parameters from

(C) R.I. Havryliv, V.V. Kochubei, I.V. Lutsyuk, 2018

R.I. Havryliv, V.V. Kochubei, I.V. Lutsyuk 
isothermal or non-isothermal thermogravimetric (TG) data have been reported and used in those investigations.

Generally, the aim of the most studies was to calculate pre-exponential factor coupled with the activation energy values in Arrhenius equation as the functions of the working conditions, sample size and heating rate.

A lot of studies have been performed to clarify the mechanism(s) of calcium carbonate thermal decomposition, often focusing on its kinetic analysis. In this regard, the traditional approach to the explanation of decarbonization mechanism and the calculation of kinetic parameters has been developed. The mentioned mechanism involves three following stages: nucleation, chemical kinetic reaction and diffusion-controlled reaction. But nowadays studies in this field are still under way to demonstrate new aspects of this problem. Some researchers suggested that the overall reaction rate of the calcination process is the component of the physical and chemical reaction rate and is controlled only by diffusion processes or diffusion-controlled reaction that proceed $[5,6]$.

Others claimed that the surface nucleation is instantaneous for a phase boundary reaction and, therefore, will have no effect on the reaction rate [7].

Some researchers have proposed a pioneer topotactic mechanism to transform calcite based on the two-step reaction rate with the diffusioncontrolled processes and the ones controlled by the first order reactions [8].

At times, it can be noted that kinetic calculations cannot be the most efficient way of identifying the reaction mechanism [9]. Vyazovkin [10] completely denied the concept of constant activation energy and suggested an alternative concept of "variable activation energy» which is an unpredictable function of temperature and/or extent of reaction.

In this way, it can be concluded that the issue of decarbonization mechanism and calculation of kinetic parameters remains open. Because of that, the theory of the thermal decomposition kinetics is increasingly complex and is traditionally based on the use of non-isothermal kinetic methods to determine kinetic constants.

Additionally, one of the drawbacks of nonisothermal approach is a very large value range of kinetic parameters. Analysis of 15 studies into calcium carbonate decomposition is reported in ref. [11] as a confirmation of this fact, showing that the difference in activation energy varies from 26 to $377 \mathrm{kcal} /$ moles and that in pre-exponential factor varies from $10^{2}$ to
$10^{69} \mathrm{~s}^{-1}$.

This is attributable to the nature of the substance, presence of impurities in the samples, particles size distribution and the medium character as well. But most probably, it can be explained by using various mathematical methods to describe the solid-state kinetics of thermal decomposition.

In other words, selecting an optimal and correct mathematical model to describe the kinetic process remains a challenge for theoretical studies.

The authors of this study concluded that further work in this field of research should be followed by using new approaches to identify the reaction mechanism of finely dispersed limestone wastes samples and selecting the best approximation model that describes experimental data in a wide range of temperatures, warming up rates and particle sizes.

Developing an adequate CFD model of the thermal decomposition reactions of finely dispersed limestone based on non-isothermal TG data will offer new prospects for going beyond traditional chemical engineering and using computer simulations in chemical processes.

\section{Material and methods}

The thermal decomposition of four various fractions of limestone waste with a particle diameter $(<50 \mu \mathrm{m} ; 50-80 \mu \mathrm{m} ; 80-140 \mu \mathrm{m}$ and $140-315 \mu \mathrm{m})$ was carried out using Q-1500 D derivatograph of the system F. Paulik, J. Paulik and L. Erdey with the registration of both analytical signals of mass loss and thermal effects via the computer. The choice of sample size is based on the requirements for a particle size that is used in a cyclone furnace. The samples were analyzed dynamically at the heating rate of $10^{\circ} \mathrm{C} / \mathrm{min}$. For each run, the temperature was raised from 25 up to $900^{\circ} \mathrm{C}$ under atmosphere of air. Thermogravimetry (TG), differential thermogravimetry (DTG) and differential thermal analysis (DTA) curves were recorded simultaneously with $0.1 \mathrm{mg}$ sensitivity. In each measurement, the weight of the samples was equal to $2 \mathrm{mg}, 50 \mathrm{mg}$ and $150 \mathrm{mg}$ for each fraction with diameter particles, respectively. The sample cells were platinum crucibles for $2 \mathrm{mg}$ samples and corundum crucibles for $50 \mathrm{mg}$ or $150 \mathrm{mg}$ samples, respectively. The limestone particles were evenly distributed over the open crucibles of $5 \mathrm{~mm}$ diameter. The reference cell was left empty. $\mathrm{Al}_{2} \mathrm{O}_{3}$ was used as a standard.

To determine the chemical compositions of limestone samples, ElvaX Light SDD (X-ray fluorescence analyzer) was used. The X-ray analyses yielded results of chemical compositions of limestone samples that are presented in Table1.

The value of apparent density $\left(>2.55 \mathrm{~g} / \mathrm{cm}^{3}\right)$ 
Table 1

Chemical compositions of limestone wastes

\begin{tabular}{c|c|c|c|c|c}
\hline $\mathrm{CaCO}_{3}$, wt.\% & $\mathrm{MgCO}_{3}$, wt.\% & $\mathrm{SiO}_{2}$, wt. $\%$ & $\mathrm{Al}_{2} \mathrm{O}_{3}$, wt. $\%$ & $\mathrm{Fe}_{2} \mathrm{O}_{3}$, wt.\% & Other impurities, wt.\% \\
\hline 93.56 & 3.24 & 2.05 & 0.20 & 0.15 & 0.8 \\
\hline
\end{tabular}

has been found. The quality of limestone wastes is regulated by the Ukrainian National Standard for Building Materials (carbonate rocks for lime production No. 2.7-109-2001 S.1).

\section{Mathematical approach}

The limestone decomposition is a solid-state endothermic reaction $\left(\Delta \mathrm{H}_{\mathrm{R}}^{0}=185.4 \mathrm{~kJ} / \mathrm{mol}\right)$ which is typical of the most decomposition processes. That is to say that inside installation (a reactor or furnace) much heat has to be supplied to the reactant to sustain the decomposition reaction.

The limestone thermal decomposition reaction can be expressed as follows:

$$
\mathrm{CaCO}_{3}(\mathrm{~s})=\mathrm{CaO}(\mathrm{s})+\mathrm{CO}_{2}(\mathrm{~g}) \text {. }
$$

The mathematical model that is used in CFD-code Ansys Fluent for simulation of the calcination is based on the Lagrangian approach where thermo-chemical reactions that occur inside a particle as well as between particle components and gas phase species are described by the single kinetic rate model or the two-competing rates model. The thermal decomposition kinetics of finely dispersed limestone can be described using the following general expression for the decomposition of a solid sample:

$$
\frac{\partial \alpha}{\partial \mathrm{t}}=\mathrm{k}(\mathrm{T}) \cdot \mathrm{f}(\alpha)
$$

where $\alpha$ is a degree of conversion; $\mathrm{k}$ is the rate constant of the process; $f(\alpha)$ is the conversion function of a solid-state reaction.

$$
\alpha=\frac{\mathrm{W}}{\mathrm{W}_{\mathrm{\kappa}}},
$$

where $\mathrm{W}$ is a current sample weight loss at the temperature; $\mathrm{W}_{\mathrm{k}}$ is the final sample weight loss at the temperature.

The mechanism of the reactions of this type can be considered as a functions of $\alpha(f(\alpha))$. The temperature dependence of the rate constant $\mathrm{k}$ of the process can be expressed by Arrhenius equation as stated above:

$$
\mathrm{k}=\mathrm{A}_{0} \cdot \mathrm{e}^{-\frac{\mathrm{E}}{\mathrm{RT}}} \text {, }
$$

where $\mathrm{A}_{0}$ is the pre-exponential factor; $\mathrm{E}$ is the activation energy; $T$ is the absolute temperature and $\mathrm{R}$ is the universal gas constant.

The definition of the conversion function $f(\alpha)$ is very important to understand the reaction mechanism of the thermal decomposition of the finely dispersed lime.

The conversion function $f(\alpha)$ for a solid-state reaction can be considered to be as follows:

$f(\alpha)=a^{m}(1-\alpha)^{n}[-\ln (1-\alpha)]^{p}$,

where $\mathrm{m}, \mathrm{n}$ and $\mathrm{p}$ are factors obtained empirically from the experiment.

Thus, kinetic investigations of decomposition reactions based on the function $f(\alpha)$ and Arrhenius equation parameters can provide information on the reaction mechanisms and the influence of process variables such as the temperature, particle size, mass of reactant, and the ambient atmosphere of the installation. Finally, these parameters can be used to create a correct CFD model.

If the temperature increases at a constant rate

$$
\frac{\partial \mathrm{T}}{\partial \mathrm{t}}=\mathrm{const}=\mathrm{q},
$$

then Eq. (1) can be expressed as follows:

$$
\frac{\partial \alpha}{\partial T}=\frac{A}{q} \cdot e^{-(E / R T)} f(\alpha)
$$

Logarithmically Eq. (6) can be written as:

$\ln \frac{\partial \alpha / d T}{f(\alpha)}=\ln \frac{A}{q}-\frac{E}{R} \cdot \frac{1}{T}$.

The integral form of the non-isothermal rate law can be presented as follows:

$g(\alpha)=A e^{-(E / R T)} d t$

and

$\mathrm{g}(\alpha)=\mathrm{A} / \mathrm{q} \int_{0}^{\mathrm{T}} \mathrm{e}^{-(\mathrm{E} / \mathrm{RT})} \mathrm{dT}$, 
where $g(\alpha)$ is the integral reaction model, defined by the expression:

$$
\int_{0}^{\alpha} \frac{d \alpha}{f(\alpha)}=g(\alpha) .
$$

According to Eq. (7), it can be plotted for different values of $f(\alpha)$ as a function of $1 / T$ and linear regression can be used to determine the activation energy $E$ and the pre-exponential factor $\mathrm{A}$ in Arrhenius equation. If the correct $\mathrm{g}(\alpha)$ function is used, a plot of $\ln (\mathrm{g}(\alpha))$ versus $1 / \mathrm{T}$ should give a straight line relationship from which the information about the reaction mechanism can be defined.

Algebraic expressions of $f(\alpha)$ and $g(\alpha)$ functions and the most common reaction mechanisms that occur in solid-state reactions are presented in Table 2) $[7,12,13]$.

Nevertheless, the use of algebraic expressions of $f(\alpha)$ and $g(\alpha)$ functions has been criticized in nonisothermal studies because Arrhenius parameters, defined on the basis of various forms of $g(\alpha)$, are correlated through the relation of compensation effect.

Therefore, some other non-Arrhenius approaches are recommended in thermal analysis by some authors. Among these approaches, the properties of TG/DTG curves in non-isothermal kinetics can be used to select possible reaction mechanisms based on «Shape method» that has been proposed by Dollimore et al. [14]. As a major tool to use «Shape method», a new flow chart with more reliable parameters can be also recommended [15]. The new flow chart is within the ranges of $10^{8}<\mathrm{A}<10^{14} \mathrm{~s}^{-1}$ and $100<\mathrm{E}<230 \mathrm{~kJ} / \mathrm{mol}$. To use this method, the values of $\alpha_{\max }$ (the maximum rate on the $\alpha$ vs. T plot) and the half width $(\Delta)$ need to be determined. The half width can be identified as $\Delta=\mathrm{T}_{2}-\mathrm{T}_{1}$, defined as the peak width on the curve of $\alpha$ vs. T measured at half height. A detailed procedure to recognize the kinetic mechanisms and the characteristic parameters of «Shape method» are presented by Haixiang et al. [15].

Thus, in this work a detailed kinetic analysis of non-isothermal data, measured at $\beta=10^{\circ} \mathrm{C} / \mathrm{min}$ by using the $g(\alpha)$ and $f(\alpha)$ model functions to determine the activation energy and the pre-exponential factor in Arrhenius equation, will be carried out. In addition, Dollimore methods [14] with Haixiang's correction [15] will be used to predict the most possible reaction mechanism and to design an adequate CFD model of limestone decomposition kinetics.

\section{Results and discussion}

The results of $\mathrm{CaCO}_{3}$ complex thermal analysis
The experimental thermograms that were recorded in the course of non-isothermal decomposition of limestone waste samples $(150 \mathrm{mg})$ are presented in Fig. 1 as TG, DTG and DTA curves. The TG curve showed that all samples were thermally stable with a minor weight loss at $\mathrm{T}<600^{\circ} \mathrm{C}$.

A rapid weight loss of the sample is observed at the temperature range of $625-955^{\circ} \mathrm{C}$ and one peak is present for all cases at $\mathrm{T}>600^{\circ} \mathrm{C}$. This corresponds to only one chemical decomposition reaction of $\mathrm{CaCO}_{3}$ with the gaseous emission of $\mathrm{CO}_{2}$ approximately at temperatures from 625 to $955^{\circ} \mathrm{C}$, i.e. when a loss of $44 \mathrm{wt} . \%$ is achieved which is an equivalent to the stoichiometric $\mathrm{CO}_{2}$ amount in $\mathrm{CaCO}_{3}$. This process is accompanied by a clear peak that appears in the DTG curve and a deep endothermic effect in the DTA curve. For samples weighing $50 \mathrm{mg}$ and $2 \mathrm{mg}$ the curves look similar and are not presented here.

According to TG data of the $\mathrm{CaCO}_{3}$ thermal decomposition, the graphs of $\alpha$ vs. T and dW/dt vs. $\mathrm{T}$ were determined. Figures $2 \mathrm{a}, 2 \mathrm{~b}, 2 \mathrm{c}$ and $2 \mathrm{~d}$ show the degree of conversion of $\alpha$ vs. T. Figures $3 a, 3 b$, $3 \mathrm{c}$ and $3 \mathrm{~d}$ show $\mathrm{dW} / \mathrm{dt}$ vs. T dependences, respectively.

A characteristic feature of the thermal decomposition of the limestone waste samples is a smooth increase of the reaction rate in the initial period, followed by a peak that occurs at the conversion degree of $\alpha_{\max }=76-78 \%$ for most samples and then drops sharply.

The kinetic analysis of thermal decomposition of limestone samples

According to Eqs. (7), (9) and Table 2, the data on experimental thermograms were processed as $f(\alpha)$ and $g(\alpha)$ vs. $1 / T$ for three different sample weights $(150 \mathrm{mg}, 50 \mathrm{mg}$ and $2 \mathrm{mg}$ ) and four different fractions with various particle diameters. For all experiments, the $f(\alpha)$ and $g(\alpha)$ vs. $1 / T$ dependences look almost the same in all cases and almost always correspond to the same equations shown in Table 2 (Eq. (11) for a nucleation mechanism, Eqs. (17), (18) and (19) for a phase boundary reaction mechanism and Eqs. (20), (21), (22), (25) and (27) for a diffusion mechanism). These equations correspond to the highest values of the correlation coefficients R2 (more than 0.99) and the maximum width of the interval in which the equation describes the experimental data that most closely relate to the topochemical process mechanism.

The values of activation energy and the preexponential factor were determined for each fraction of particles and weight of the sample following the algebraic expression of functions $f(\alpha)$ in Eq. (7). 
Table 2

Solid-state rate and algebraic expressions of functions $g(\alpha)$ and $f(\alpha)$ and their corresponding mechanism

\begin{tabular}{c|c|c|c|c|c}
\hline No & Rate mechanism & Symbol & $\mathrm{g}(\alpha)$ & $\mathrm{f}(\alpha)$ & Function name \\
\hline \multicolumn{7}{c}{ I. Chemical process or mechanism non-invoking equations } \\
\hline 1 & Chemical reaction & $\mathrm{F}_{1 / 3}$ & $1-(1-\alpha)^{2 / 3}$ & $(3 / 2)(1-\alpha)^{1 / 3}$ & One-third order \\
\hline 2 & Chemical reaction & $\mathrm{F}_{3 / 4}$ & $1-(1-\alpha)^{1 / 4}$ & $4(1-\alpha)^{3 / 4}$ & Three-quarters order \\
\hline 3 & Chemical reaction & $\mathrm{F}_{3 / 2}$ & $(1-\alpha)^{-1 / 2}-1$ & $2(1-\alpha)^{3 / 2}$ & One and a half order \\
\hline 4 & Chemical reaction & $\mathrm{F}_{2}$ & $(1-\alpha)^{-1}-1$ & $(1-\alpha)^{2}$ & Second order \\
\hline 5 & Chemical reaction & $\mathrm{F}_{3}$ & $(1-\alpha)^{-2}-1$ & $(1 / 2)(1-\alpha)^{3}$ & Third order \\
\hline 6 & \multicolumn{5}{|c|}{ II. Acceleratory rate equations } \\
\hline 7 & Nucleation & $\mathrm{P}_{3 / 2}$ & $\alpha^{3 / 2}$ & $(2 / 3) \alpha^{-1 / 2}$ & Mampel power law \\
\hline 8 & Nucleation & $\mathrm{P}_{1 / 2}$ & $\alpha^{1 / 2}$ & $2 \alpha^{1 / 2}$ & Mampel power law \\
\hline 9 & Nucleation & $\mathrm{P}_{1 / 3}$ & $\alpha^{1 / 3}$ & $3 \alpha^{3 / 4}$ & Mampel power law \\
\hline 10 & Nucleation & $\mathrm{P}_{1 / 4}$ & $\alpha^{1 / 4}$ & $4 \alpha^{3 / 4}$ & Mampel power law \\
\hline
\end{tabular}

III. Sigmoid rate equations or random nucleation and subsequent growth

\begin{tabular}{|c|c|c|c|c|c|}
\hline 11 & \begin{tabular}{|c|} 
Assumed random nucleation \\
and its subsequent growth, $n=1$
\end{tabular} & $\mathrm{~A}_{1}, \mathrm{~F}_{1}$ & $-\ln (1-\alpha)$ & $(1-\alpha)$ & Avrami-Erofeev equation \\
\hline 12 & $\begin{array}{l}\text { Assumed random nucleation } \\
\text { and its subsequent growth, } \\
n=1.5\end{array}$ & $\mathrm{~A}_{3 / 2}$ & {$[-\ln (1-\alpha)]^{2 / 3}$} & $3 / 2(1-\alpha)[-\ln (1-\alpha)]^{1 / 3}$ & Avrami-Erofeev equation \\
\hline 13 & $\begin{array}{c}\text { Assumed random nucleation } \\
\text { and its subsequent growth, } n=2\end{array}$ & $\mathrm{~A}_{2}$ & {$[-\ln (1-\alpha)]^{1 / 2}$} & $2(1-\alpha)[-\ln (1-\alpha)]^{1 / 2}$ & Avrami-Erofeev equation \\
\hline 14 & $\begin{array}{c}\text { Assumed random nucleation } \\
\text { and its subsequent growth, } n=3\end{array}$ & $\mathrm{~A}_{3}$ & {$[-\ln (1-\alpha)]^{1 / 3}$} & $3(1-\alpha)[-\ln (1-\alpha)]^{2 / 3}$ & Avrami-Erofeev equation \\
\hline 15 & $\begin{array}{c}\text { Assumed random nucleation } \\
\text { and its subsequent growth, } n=4\end{array}$ & $\mathrm{~A}_{4}$ & {$[-\ln (1-\alpha)]^{1 / 4}$} & $4(1-\alpha)[-\ln (1-\alpha)]^{3 / 4}$ & Avrami-Erofeev equation \\
\hline 16 & Branching nuclei & $\mathrm{A}_{\mathrm{u}}$ & $\ln [\alpha /(1-\alpha)]$ & $\alpha(1-\alpha)$ & Prout-Tomkins equation \\
\hline \multicolumn{6}{|c|}{ IV. Deceleratory rate equation } \\
\hline \multicolumn{6}{|c|}{ (Phase boundary reaction) } \\
\hline 17 & Contracting disk & $\mathrm{R}_{1}, \mathrm{~F}_{0}, \mathrm{P}_{1}$ & $\alpha$ & $(1-\alpha)^{0}$ & Power law \\
\hline 18 & Contracting cylinder & $\mathrm{R}_{2}, \mathrm{~F}_{1 / 2}$ & $1-(1-\alpha)^{1 / 2}$ & $2(1-\alpha)^{1 / 2}$ & Power law \\
\hline 19 & Contracting sphere & $\mathrm{R}_{3}, \mathrm{~F}_{2 / 3}$ & $1-(1-\alpha)^{1 / 3}$ & $3(1-\alpha)^{2 / 3}$ & Power law \\
\hline \multicolumn{6}{|c|}{ (Based on the diffusion mechanism) } \\
\hline 20 & One-dimensional diffusion & $\mathrm{D}_{1}$ & $\alpha^{2}$ & $1 / 2 \alpha$ & Parabola law \\
\hline 21 & Two-dimensional diffusion & $\mathrm{D}_{2}$ & $\alpha+(1-\alpha) \ln (1-\alpha)$ & {$[-\ln (1-\alpha)]^{-1}$} & Valensi equation \\
\hline 22 & $\begin{array}{c}\text { Three-dimensional diffusion, } \\
\text { spherical symmetry }\end{array}$ & $\mathrm{D}_{3}$ & {$\left[1-(1-\alpha)^{1 / 3}\right]^{2}$} & $(3 / 2)(1-\alpha)^{2 / 3}\left[1-(1-\alpha)^{1 / 3}\right]^{-1}$ & Jander equation \\
\hline 23 & $\begin{array}{c}\text { Three-dimensional diffusion, } \\
\text { cylindrical symmetry }\end{array}$ & $\mathrm{D}_{4}$ & $1-2 \alpha / 3-(1-\alpha)^{2 / 3}$ & $(3 / 2)\left[(1-\alpha)^{-1 / 3}-1\right]^{-1}$ & $\begin{array}{c}\text { Ginstling-Brounstein } \\
\text { equation } \\
\end{array}$ \\
\hline 24 & Three-dimensional diffusion & $\mathrm{D}_{5}$ & {$\left[(1-\alpha)^{-1 / 3}-1\right]^{2}$} & $(3 / 2)(1-\alpha)^{4 / 3}\left[(1-\alpha)^{-1 / 3}-1\right]^{-1}$ & $\begin{array}{l}\text { Zuravlev, Lesokhin, } \\
\text { Tempelman equation }\end{array}$ \\
\hline 25 & Three-dimensional diffusion & $\mathrm{D}_{6}$ & {$\left[(1+\alpha)^{1 / 3}-1\right]^{2}$} & $(3 / 2)(1+\alpha)^{2 / 3}\left[(1+\alpha)^{1 / 3}-1\right]^{-1}$ & anti-Jander equation \\
\hline 26 & Three-dimensional diffusion & $\mathrm{D}_{7}$ & $1+2 \alpha / 3-(1+\alpha)^{2 / 3}$ & $(3 / 2)\left[(1+\alpha)^{-1 / 3}-1\right]^{-1}$ & $\begin{array}{c}\begin{array}{c}\text { anti-Ginstling-Brounstein } \\
\text { equation }\end{array} \\
\end{array}$ \\
\hline 27 & Three-dimensional diffusion & $\mathrm{D}_{8}$ & {$\left[(1+\alpha)^{-1 / 3}-1\right]^{2}$} & $(3 / 2)(1+\alpha)^{4} / 3\left[(1+\alpha)^{-1 / 3}-1\right]^{-1}$ & $\begin{array}{l}\text { anti-Zuravlev, Lesokhin, } \\
\text { Tempelman equation }\end{array}$ \\
\hline
\end{tabular}




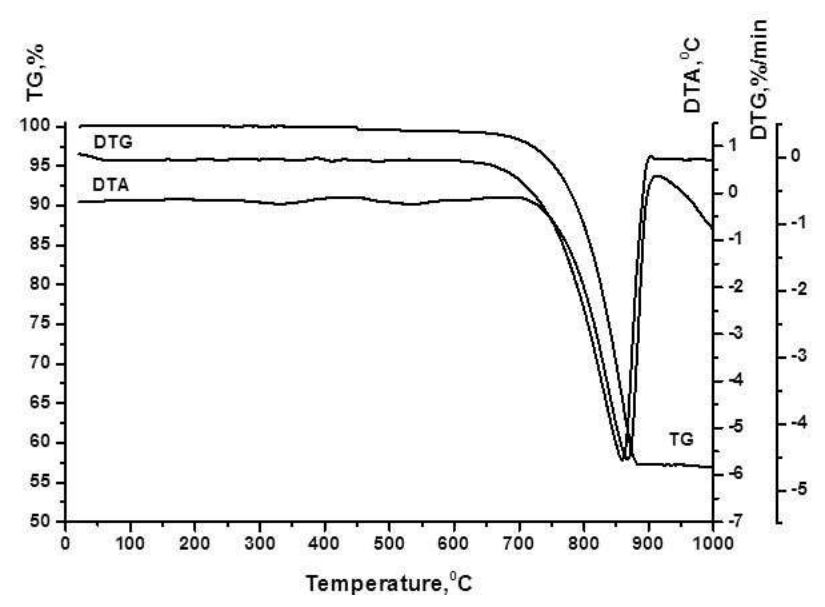

a

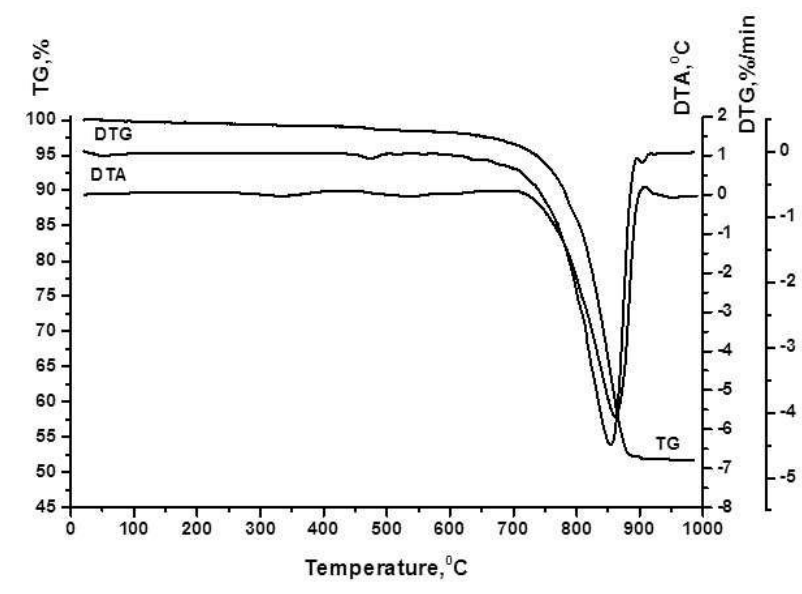

c

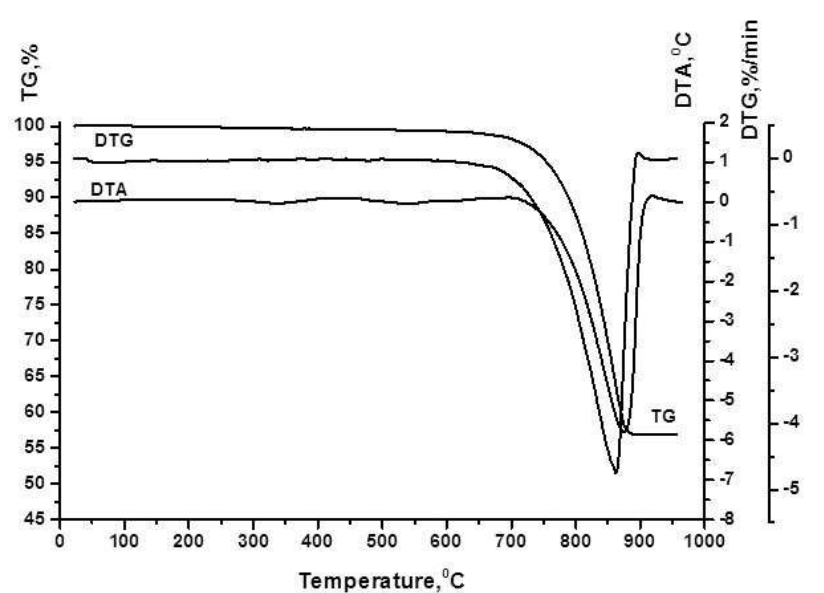

b

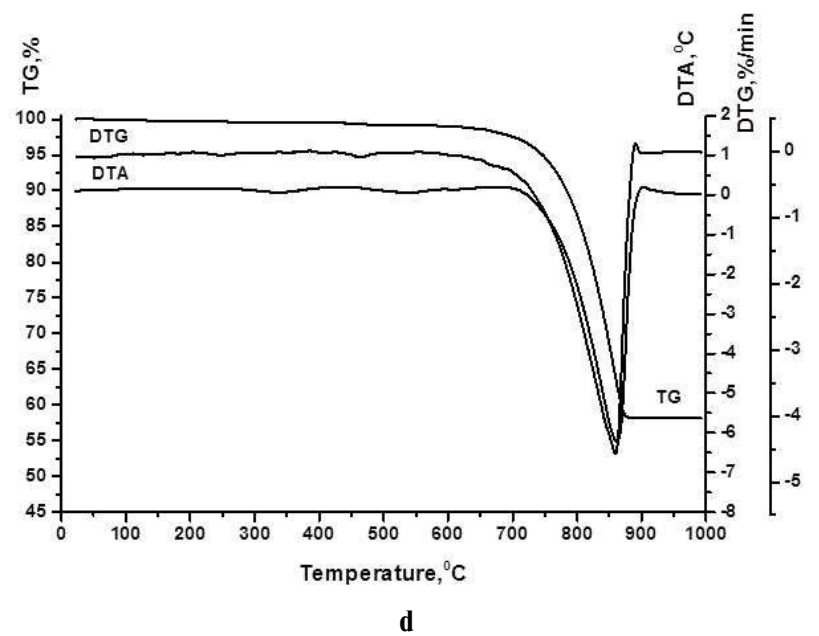

Fig. 1. The thermogram of the sample weight of $150 \mathrm{mg}$ for different particle fractions: a - particles of $140-315 \mu \mathrm{m}$ diameter; $\mathrm{b}-$ particles of $80-140 \mu \mathrm{m}$ diameter; $\mathrm{c}-$ particles of 50-80 $\mu \mathrm{m}$ diameter; $\mathrm{d}-$ particles of $<50 \mu \mathrm{m}$ diameter

Depending on the reaction mechanism, the values of activation energy range from 165 to $560 \mathrm{~kJ} / \mathrm{mol}$.

Figure 4 presents the linear relationships between $f(\alpha)$ and $1 / T$ for the limestone samples (150 mg weight) of different particle fractions.

The experimental data presented above indicate that there is not a single mechanism that controls the process. This again confirms that the description of the topochemical reaction kinetics on the basis of simplified model dependencies in many cases leads to the receipt of rather contradictory data.

It should also be pointed out that the kinetic model equations are derived for a monodisperse sample. The samples are polydisperse systems under experimental conditions even within the selected fractions. This is particularly true for the samples of $140-315 \mu \mathrm{m}$ and $80-140 \mu \mathrm{m}$ diameters.

It can be assumed that the smallest particles will be decomposed completely during the reaction earlier than the larger ones. Due to this fact, the form of the kinetic equation is distorted and the order of the reaction changes. This error becomes greater till the end of the reaction.

As the particles of calcium carbonate are very small, it is reasonable to assume that the reaction in the particles proceeds according to a shrinking core model, i.e. the mechanism of volume contraction.

To define a possible form of equations in the kinetic region, a flow chart («Shape method») has been used which is determined by some features of the conversion curves (or TG/DTG curves) for different kinetic models $[14,15]$.

The results are presented in Table 3 as values of some parameters that give information on the nature of thermal decomposition in the range of $0 \leq \alpha(T) \leq 1: T_{\max }$ (the maximum temperature as shown by the peak on $d \alpha / d T$ vs. T curve, Fig. 3 ), $\alpha_{\max }$ (the maximum rate on $\alpha$ vs. T plot, Fig. 2), $\mathrm{S}$ (shape 


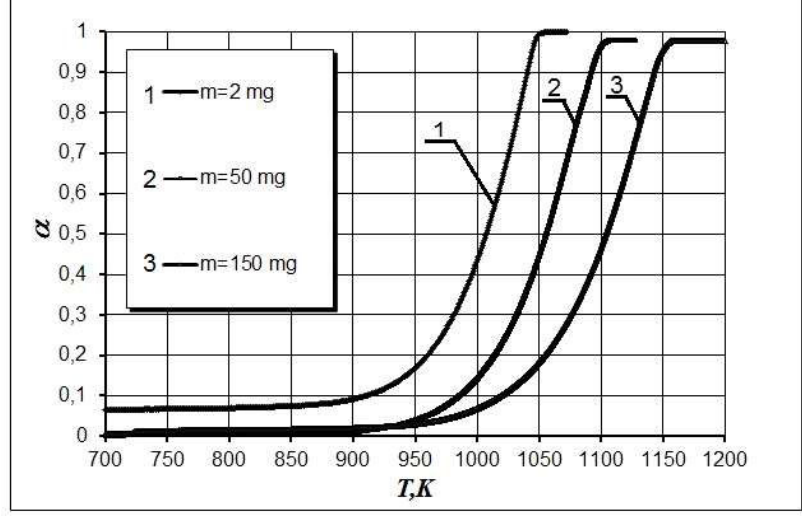

a

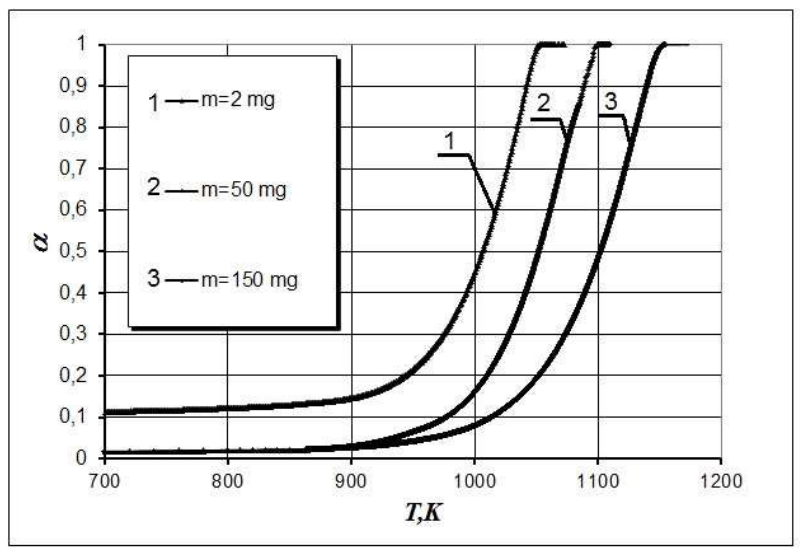

c

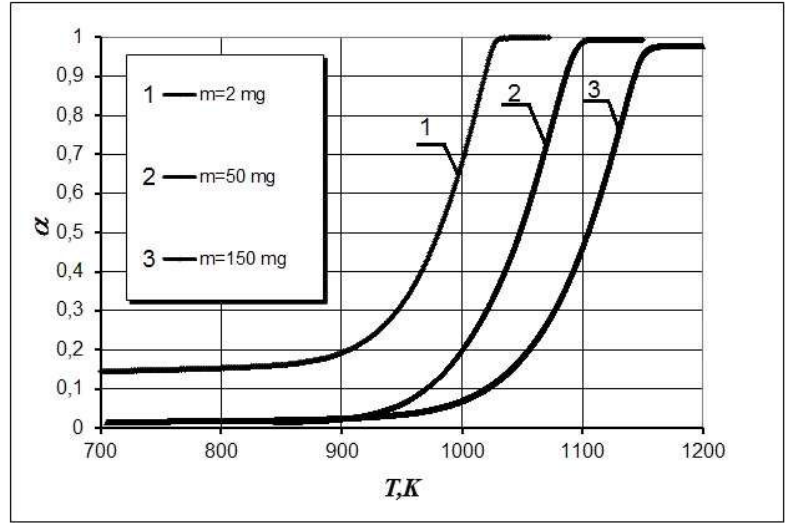

b

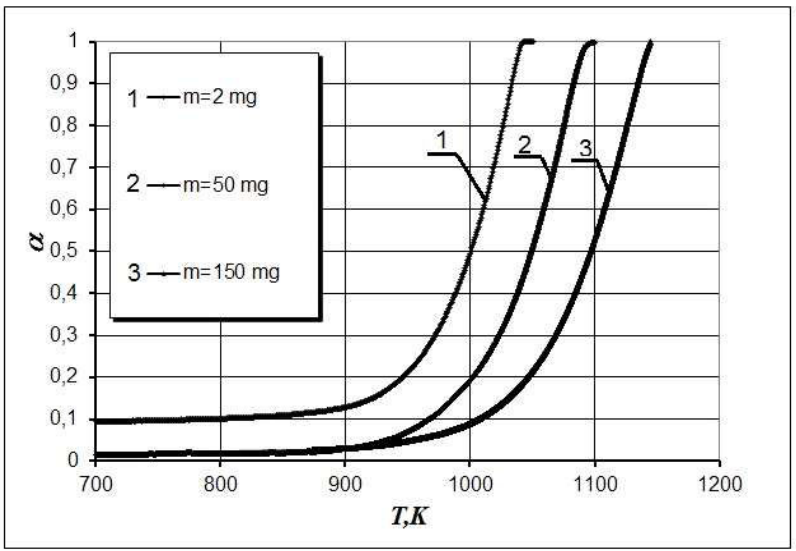

d

Fig. 2. The $\alpha=f(T)$ curves for thermal decomposition of limestone samples: a - particles of $140-315 \mu \mathrm{m}$ diameter; $\mathrm{b}-$ particles of $80-140 \mu \mathrm{m}$ diameter; $\mathrm{c}-$ particles of 50-80 $\mu \mathrm{m}$ diameter; $\mathrm{d}-$ particles of $<50 \mu \mathrm{m}$ diameter

factor, $\left.S=\left(T_{\max }-T_{1}\right) /\left(T_{2}-T_{\max }\right)\right), T_{i}$ and $T_{f}$ (the initial $\left(\mathrm{T}_{\mathrm{i}}\right)$ and final $\left(\mathrm{T}_{\mathrm{f}}\right)$ temperatures on $\alpha$ vs. T plot, Fig. 2) and the half width $(\Delta)$.

The results show that the values of main parameters vary depending on the particle size and sample weight. Generally, all the decompositions belong to group $\mathrm{B}$, which includes mechanisms $\mathrm{R}_{2}$, $\mathrm{R}_{3}, \mathrm{D}_{1}-\mathrm{D}_{3}, \mathrm{D}_{6}, \mathrm{D}_{8}$ according to the shape factor $\mathrm{S}>1$ [14]. Practically, all the values of $\alpha_{\max }$ vary between 0.7 and 0.8 , implying that $R_{2}$, and $D_{4}$ are the possible mechanisms.

The half width indicated the low value ranges from 17 to 61 for low weight samples and high value ranges from 60 to 76 for large weight samples, respectively. According to Dollimore's flow chart for the above half-width values, the three-dimensional diffusion model $\mathrm{D}_{4}$ can be recommended [14]. However, the diffusion effect on the decarbonization kinetics is ambiguous. It seems plausible that the inhibition of diffusion process is determined by the thickness of the layer of dispersed material in the sample for the samples weighing $150 \mathrm{mg}$. Thus, the samples of $150 \mathrm{mg}$ should be used with caution as a base for the mathematical model to calculate kinetics at high values of $\alpha$ conversion. Furthermore, the results presented above for $f(\alpha)$ and $g(\alpha)$ show that $\mathrm{D}_{4}$ reaction mechanism is not able to control the process.

For as much as possible approximated representation of reaction conditions that take place in the real cyclone type furnaces and the determination of the kinetic equation, it is necessary to perform a single-particle thermal analysis. This cannot be achieved under the experimental conditions due to relation to the sensitivity limit of the device itself. But, the samples of the material of $2 \mathrm{mg}$ weight are in good agreement with these conditions.

The revised flow chart proposed by Haixiang et al. [15] gives new half-width values in recognizing the reaction mechanisms. According to the above mentioned, a new half width, $\Delta$, varies between 14.5 


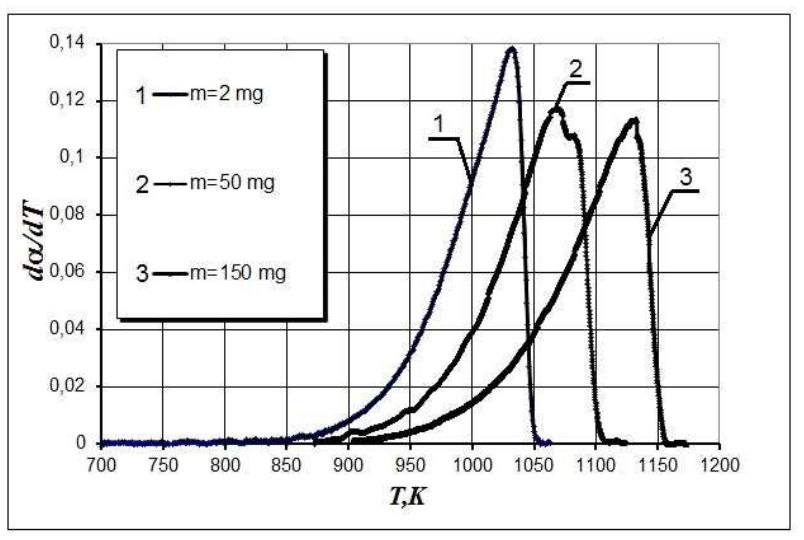

$\mathbf{a}$

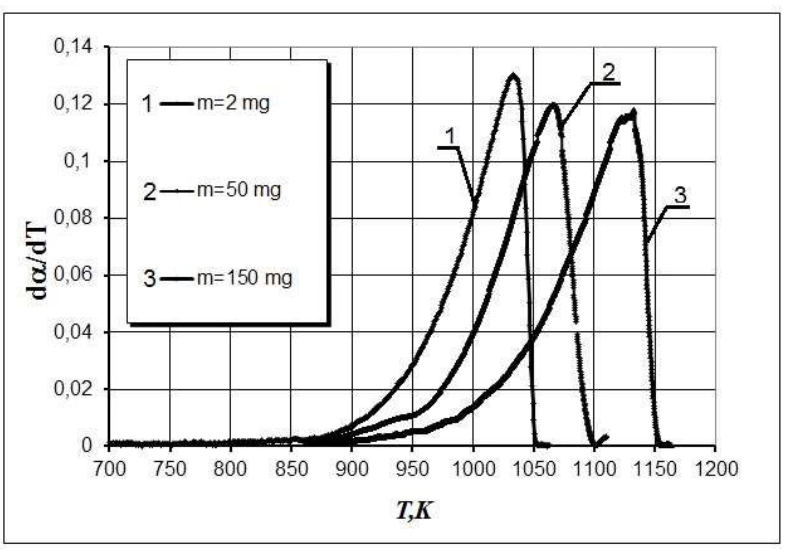

c

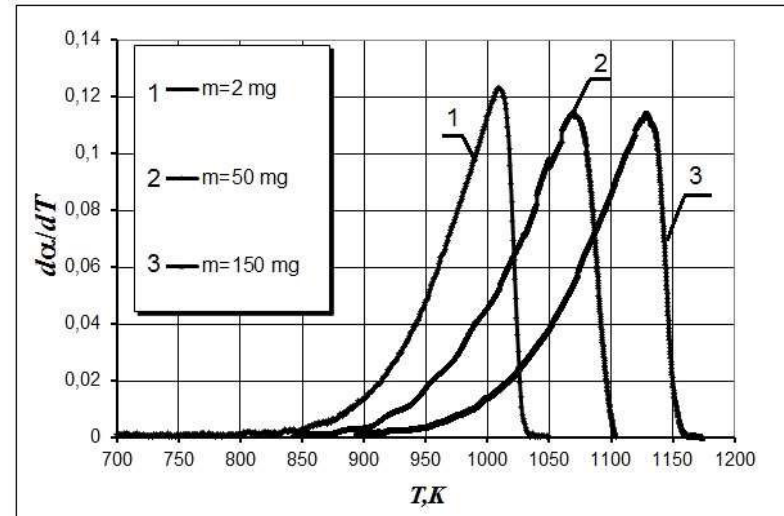

b

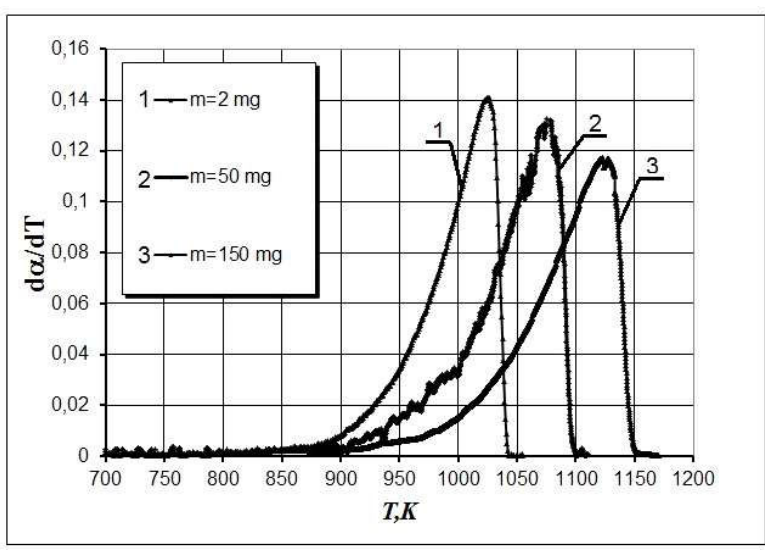

d

Fig. 3. The $d \alpha / d T=f(T)$ curves for thermal decomposition of limestone samples: a - particles of $140-315 \mu \mathrm{m}$ diameter; $\mathrm{b}-$ particles of $80-140 \mu \mathrm{m}$ diameter; $\mathrm{c}-$ particles of $50-80 \mu \mathrm{m}$ diameter; $\mathrm{d}-$ particles of $<50 \mu \mathrm{m}$ diameter

Table 3

The parameters related to characteristic feature of the limestone decomposition mechanism from TG data

\begin{tabular}{|c|c|c|c|c|c|c|c|c|}
\hline \multirow{2}{*}{ Fraction } & \multicolumn{8}{|c|}{ Parameters } \\
\hline & $\mathrm{T}_{\mathrm{i}}$ & $\mathrm{T}_{\mathrm{f}}$ & $\mathrm{T}_{1}, \mathrm{~K}$ & $\mathrm{~T}_{2}, \mathrm{~K}$ & $\mathrm{~T}_{\max }, \mathrm{K}$ & $\alpha_{\max }, \%$ & $\mathrm{~S}$ & Half width $(\Delta), \mathrm{K}$ \\
\hline $140-315 \mu \mathrm{m}$ & Diffuse & Sharp & 1025 & 1042 & 1032 & 77.5 & 0.7 & 17 \\
\hline $80-140 \mu \mathrm{m}$ & Diffuse & Sharp & 961 & 1022 & 1008 & 77.2 & 3.35 & 61 \\
\hline $50-80 \mu \mathrm{m}$ & Diffuse & Sharp & 988 & 1045 & 1033 & 77.5 & 3.75 & 57 \\
\hline$<50 \mu \mathrm{m}$ & Diffuse & Sharp & 982 & 1035 & 1025 & 77.6 & 4.3 & 53 \\
\hline \multicolumn{9}{|c|}{ Sample weight $50 \mathrm{mg}$} \\
\hline $140-315 \mu \mathrm{m}$ & Diffuse & Sharp & 1019 & 1093 & 1068 & 64 & 1.96 & 74 \\
\hline $80-140 \mu \mathrm{m}$ & Diffuse & Sharp & 1013 & 1089 & 1070 & 72.15 & 3 & 76 \\
\hline $50-80 \mu \mathrm{m}$ & Diffuse & Sharp & 1017 & 1082 & 1066 & 65.5 & 4.06 & 65 \\
\hline$<50 \mu \mathrm{m}$ & Diffuse & Sharp & 1030 & 1090 & 1075 & 78.4 & 3 & 60 \\
\hline \multicolumn{9}{|c|}{ Sample weight $150 \mathrm{mg}$} \\
\hline $140-315 \mu \mathrm{m}$ & Diffuse & Sharp & 1071 & 1144 & 1132 & 79 & 6.08 & 73 \\
\hline $80-140 \mu \mathrm{m}$ & Diffuse & Sharp & 1072 & 1144 & 1127 & 73.4 & 3.23 & 72 \\
\hline $50-80 \mu \mathrm{m}$ & Diffuse & Sharp & 1071 & 1143 & 1132 & 82 & 5.54 & 72 \\
\hline$<50 \mu \mathrm{m}$ & Diffuse & Sharp & 1065 & 1140 & 1123 & 77 & 3.41 & 75 \\
\hline
\end{tabular}




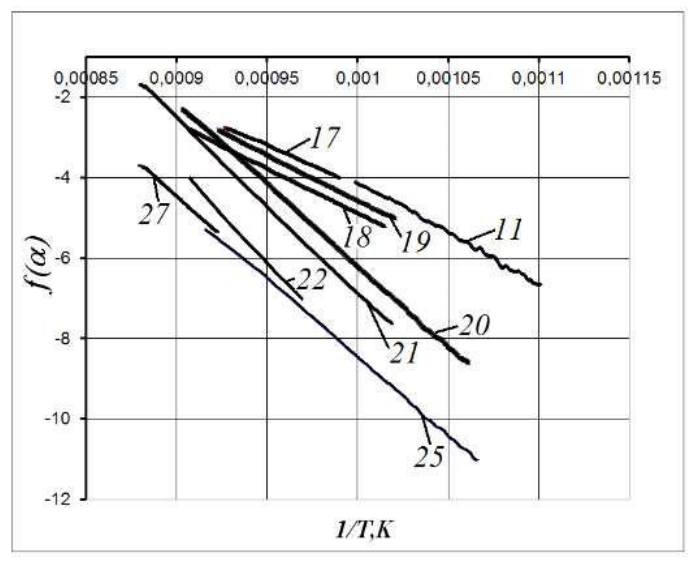

a

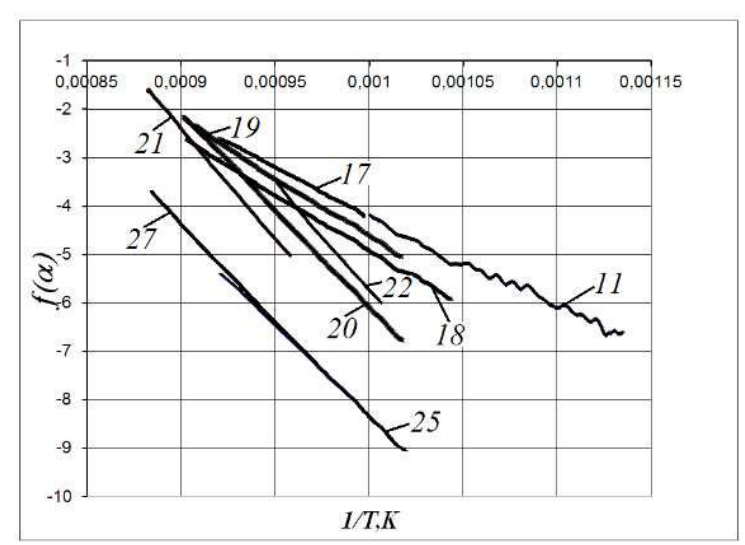

c

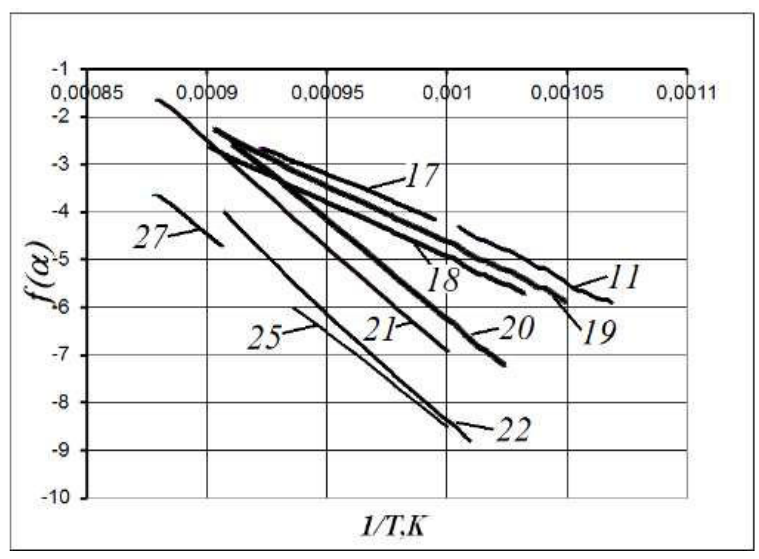

b

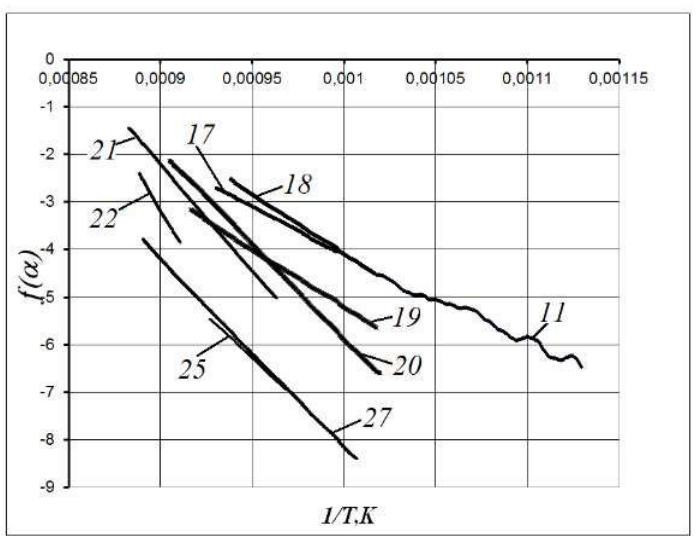

d

Fig. 4. Plots of linear relationships between $\mathrm{f}(\alpha)$ and $1 /$ T for the samples weighing $150 \mathrm{mg}$ : a- particles of $140-315 \mu \mathrm{m}$ diameter; $\mathrm{b}$ - particles of $80-140 \mu \mathrm{m}$ diameter; $\mathrm{c}-$ particles of $50-80 \mu \mathrm{m}$ diameter; $\mathrm{d}-$ particles of $<50 \mu \mathrm{m}$ diameter

and 72.7, for $\alpha_{\max }$ between 0.71 and 0.77 , implying that $R_{2}$ is the possible mechanism of reaction. This reaction mechanism corresponds to all samples weighing $2 \mathrm{mg}$ as well as two samples weighing $50 \mathrm{mg}(<50 \mu \mathrm{m}$ and $50-80 \mu \mathrm{m})$. Other samples of $50 \mathrm{mg}$ and $150 \mathrm{mg}$ weight have a half-width value that is very close to 72.7 .

The activation energy values according to the $\mathrm{R}_{2}$ kinetic model account for approximately 176$212 \mathrm{~kJ} / \mathrm{mol}$ and are similar to other equation numbers (Table 2 ) for the phase boundary reactions $\left(R_{1}, R_{3}\right)$. These values are found to be in good agreement with the data presented in the literature.

\section{Proposed CFD model}

The proposed approach for determining the reaction mechanism is appropriate to describe the reaction in the kinetic region ( $\alpha$ varies ca. from 0.1 to 0.9$)$. For the initial stage $(\alpha<0.2)$, the choice of the model equation and values of the kinetic constants are unclear.

According to the results presented as the linear relationships between $\mathrm{f}(\mathrm{a})$ and $1 / \mathrm{T}$, the initial stage is well described by the nucleation model $\left(\mathrm{A}_{1}, \mathrm{~F}_{1}\right)$ with the slightly higher values of activation energy, that is about $210-220 \mathrm{~kJ} / \mathrm{mol}$.

It is clear that a region for $\left(A_{1}, F_{1}\right)$ overlaps with a region of $R_{2}$ which indicates that it is not possible to exactly distinguish between these two reaction mechanisms for different weights of samples.

These data agree well with the curve $\alpha=f(T)$ that is shown in Fig. 2, where the initial nucleation period is observed up to $5-7 \%$ for the samples of large mass and $10-15 \%$ for the ones of smaller mass, respectively.

Similar results were reported by RodriguezNavarro et al. [8]. For a single crystal of $\mathrm{CaCO}_{3}$ (ca. $2 \times 2 \times 1 \mathrm{~mm}$ in size), the initial period $(\alpha<0.2)$ is characterized by high energy activation values. But the author claims that the diffusion resistance of $\mathrm{CO}_{2}$ controls the reaction through a product layer at the initial stages of the process $(\alpha<0.2)$; consequently, the activation energy increases as well. 
The presented results allow us to propose a CFD model based on a two-stage reaction mechanism:

$\mathrm{k}_{1}=\mathrm{A}_{1} \exp \left(-\mathrm{E}_{1} / \mathrm{RT}\right)$;

$\mathrm{k}_{2}=\mathrm{A}_{2} \exp \left(-\mathrm{E}_{2} / \mathrm{RT}\right)$,

where $k_{1}$ and $k_{2}$ are competing rates that may be controlled according to different a ranges. As it can be seen from the obtained results, the activation energy values $E_{1}=210-220 \mathrm{~kJ} / \mathrm{mol}$ for the initial stage $(\alpha<0.1-0.15)$ and $\mathrm{E}_{2}=176-212 \mathrm{~kJ} / \mathrm{mol}$ for the kinetic region $(\alpha>0.1-0.15)$ can be recommended.

\section{Conclusions}

The thermal decomposition kinetics of finely dispersed limestone waste from Pustomyty lime production plant (Ukraine) has been studied. To propose an effective CFD model based on the mechanism of calcination reaction rate, the effects of particle sizes and sample mass were studied by using TG analysis.

We concluded that the totally clear choice of the reaction model is practically impossible if it is based solely on the existing non-isothermal TG data by using a model-fitting method. The meaningful conclusions concerning the real mechanism of the decomposition process under investigation should be based on the asymmetry of DTG (differential thermogravimetry) as «Shape method» with the complementary use of the revised flow-chart.

The experimental results have been considered by the methods considered in the study; they strongly indicate that the most possible rate that controls the step is $R_{2}$ kinetic model for a varying between 0.1 and 0.9. It is also shown that the reaction mechanism is difficult to be determined by this method for the initial reaction stage $(\alpha<0.1)$.

The effective activation energy values for the initial stage are found to be in the kinetic region of ca. $200 \mathrm{~kJ} / \mathrm{mol}$ and $220 \mathrm{~kJ} / \mathrm{mol}$, respectively.

It is proposed to use these parameters to create the CFD model based on a two-stage reaction mechanism.

The date on the control mechanism, the kinetic equations and activation energy values presented in the study are found to be in a very good agreement with the conclusions of other scientists.

\section{REFERENCES}

1. Numerical simulation of the complex thermal processes in a vortexing precalciner / Mei S., Xie J., Chen X., He F., Yang H.,
Jin M. // Appl. Therm. Eng. - 2017. - Vol.125. - P.652-661.

2. Numerical evaluation of different pulverized coal and solid recovered fuel co-firing modes inside a large-scale cement calciner / Mikulcic H., von Berg E., Vujanovic M., Wang X., Tan H., Duic N. // Appl. Energy. - 2016. - Vol.184. - P.12921305.

3. Havryliv R., Maystruk V., Biliak V. Development of a numerical model for gas-solid flow in the industrial cyclonecalciner furnace // East.-Europ. J. Enterprise Technol. - 2015. - Vol.3/8(75). - P.14-21.

4. Directions of cyclone furnace development / Zarzycki R., Kobylecki R., Kratofil M., Bis Z. // Polityka Energetyczna. 2014. - Vol.17. - No. 4. - P.249-262.

5. Zhao Y.T., Sun T.S., Sun B. The thermal decomposition of calcium carbonate // Chin. Chem. Lett. - 2001. - Vol.12. P.745-746.

6. Elder J.P., Ready V.B. The kinetics of the thermal degradation of calcium carbonate // J. Therm. Anal. - 1986. Vol.31. - P.395-405.

7. Georgieva V., Vlaev L., Gyurova K. Non-isothermal degradation kinetics of $\mathrm{CaCO}_{3}$ from different origin // J. Chem. - 2013. - Article No. 872981.

8. Thermal decomposition of calcite: mechanisms of formation and textural evolution of $\mathrm{CaO}$ nanocrystals / RodriguezNavarro C., Ruiz-Agudo E., Luque A., Rodriguez-Navarro A.B., Ortega-Huertas M. // Am. Mineral. - 2009. - Vol.94. - P.578593.

9. Galwey A.K., Brown M.E. Solid-state decompositions stagnation or progress? // J. Therm. Anal. Calorim. - 2000. Vol.60. - P.863-877.

10. Vyazovkin $S$. Kinetic concepts of thermally stimulated reactions in solids: a view from a historical perspective // Int. Rev. Phys. Chem. - 2000. - Vol.19. - P.45-60.

11. Prasad T.P., Kanungo S.B., Ray H.S. Non-isothermal kinetics: some merits and limitations // Thermochim. Acta. 1992. - Vol.203. - P.503-514.

12. Ninan K.N., Krishnan K., Krishnamurthy V.N. Kinetics and mechanism of thermal decomposition of insitu generated calcium carbonate // J. Therm. Anal. - 1991. - Vol.37. - P.15331543 .

13. Khawam A., Flanagan D.R. Solid-state kinetic models: basics and mathematical fundamentals // J. Phys. Chem. B. 2006. - Vol.110. - P.17315-17328.

14. Dollimore D., Tong P., Alexander K.S. The kinetic interpretation of the decomposition of calcium carbonate by use of relationships other than the Arrhenius equation // Thermochim. Acta. - 1996. - Vol.282-283. - P.13-27.

15. Haixiang C., Naian L., Weitao Z. Critical study on the identification of reaction mechanism by the shape of TG/DTG curves // Solid State Sci. - 2010. - Vol.12. - P.455-460.

Received 06.03.2018 


\section{КІНЕТИЧНИЙ АНАЛІЗ ТЕРМІЧНОГО РОЗКЛАДУ ТОНКОДИСПЕРСНИХ ВАПНЯКОВИХ ВІДХОДІВ ДЛЯ СТВОРЕННЯ КОМП'ЮТЕРНОЇ ІМІТАЦІЙНОЇ МОДЕЛІ}

\section{Р.І. Гаврилів, В.В. Кочубей, І.В. Луцюк}

Ірунтуючись на аналізі існуючих даних термічного розкладу $\mathrm{CaCO}_{3}$, які наведені в літературі, зроблено висновок про те, що створення компактної інженерної CFD-моделі (моделі обчислювальної гідродинаміки) для кальцинації вапняку є актуальним. Ця модель може бути основана на термогравіметричних даних і стандартних математичних алгоритмах аnроксимації. Термічне розкладання дрібнодисперсних частинок відходів вапняку різних фракцій розмірами менше, ніж 315 мкм, здійснювалися на дериватографi Q-1500 D (системи F. Paulik, J. Paulik ma L. Erdey) в неізотермічних умовах. На основі диференціальних рівнянь топохімічної твердотільної кінетики асиметрії кривих DTG (диференціальна термогравіметрія) значення енергії активації, предекспоненціального множника в рівнянні Арреніуса, а також механізм реакції термічного розкладання частинок визначали за результатами експериментів, здійснених у неізотермічних умовах зі швидкістю нагрівання $10^{\circ} \mathrm{C} /$ хв у діапазоні температур від 600 до $900^{\circ} \mathrm{C}$. Отримані результати дають підстави запропонувати новий інженерний підхід для моделювання термічного розкладання вапнякових відходів за допомогою двоступеневого механізму твердотільної кінетики в комериійному CFD-коді Ansys Fluent i можуть бути використані в хімічній інженерії для створення нового високоефективного обладнання.

Ключові слова: енергія активації, відходи вапняку, термічний розклад, топохімічна реакція, швидкість реакції, CFD-моделювання.

\section{KINETIC ANALYSIS OF THERMAL DECOMPOSITION OF FINELY DISPERSED LIMESTONE WASTES FOR THE DEVELOPMENT OF A NUMERICAL SIMULATION MODEL}

\section{R.I. Havryliv, V.V. Kochubei, I.V. Lutsyuk \\ Lviv Polytechnic National University, Lviv, Ukraine}

On the basis of the analysis of known literature data on $\mathrm{CaCO}_{3}$ thermal decomposition, it is concluded that the development of a compact engineering CFD model (computational fluid dynamics) for limestone calcination is a topical issue. This model can be based on thermogravimetric data and standard mathematical approximation algorithms. Experiments on thermal decomposition of finely dispersed limestone waste particles of different fractions less than $315 \mu \mathrm{m}$ were carried out using a Q-1500D derivatograph(system F. Paulik, J. Paulik and L. Erdey) under non-isothermal conditions. Based on differential equations of topochemical solid-state kinetics and the asymmetry of differential thermogravimetry (DTG) curves, the values of activation energy, pre-exponential factor in Arrhenius equation were calculated and the reaction mechanism of the thermal decomposition of particles was determined from the results of nonisothermal experiments performed at the heating rate of $10^{\circ} \mathrm{C} / \mathrm{min}$ in a temperature range of 600 to $900^{\circ} \mathrm{C}$. A new engineering approach was developed to the CFD simulation of the thermal decomposition of limestone wastes by means of a two-step mechanism of solid-state kinetics using commercial CFD code ANSYS Fluent. The findings could be used in chemical engineering to produce new highly efficient equipment.

Keywords: activation energy; limestone wastes; thermal decomposition;topochemical reaction; reaction rate; CFD modeling.

\section{REFERENCES}

1. Mei S., Xie J., Chen X., He F., Yang H., Jin M. Numerical simulation of the complex thermal processes in a vortexing precalciner. Applied Thermal Engineering, 2017, vol.125, pp. 652-661.

2. Mikulcic H., von Berg E., Vujanovic M., Wang X., Tan H., Duic N. Numerical evaluation of different pulverized coal and solid recovered fuel co-firing modes inside a large-scale cement calciner. Applied Energy, 2016, vol.184, pp. 1292-1305.

3. Havryliv R., Maystruk V., Biliak V. Development of a numerical model for gas-solid flow in the industrial cyclonecalciner furnace.Eastern-European Journal of Enterprise Technologies, 2015, vol. 3/8(75), pp.14-21.

4. Zarzycki R., Kobylecki R., Kratofil M., Bis Z. Directions of cyclone furnace development. PolitykaEnergetyczna, 2014, vol. 17, pp. 249-262.

5. Zhao Y.T., Sun T.S., Sun B. The thermal decomposition of calcium carbonate. Chinese Chemical Letters, 2001, vol. 12, pp. 745-746.

6. Elder J.P., Ready V.B.The kinetics of the thermal degradation of calcium carbonate. Journal of Thermal Analysis, 1986, vol. 31, pp. 395-405.

7. Georgieva V., Vlaev L., Gyurova K. Non-isothermal degradation kinetics of $\mathrm{CaCO}_{3}$ from different origin. Journal of Chemistry, 2013, vol. 2013, article no. 872981.

8. Rodriguez-Navarro C., Ruiz-Agudo E., Luque A., Rodriguez-Navarro A.B., Ortega-Huertas M. Thermal decomposition of calcite: mechanisms of formation and textural evolution of $\mathrm{CaO}$ nanocrystals. American Mineralogist, 2009, vol. 94, pp. 578-593.

9. Galwey A.K., Brown M.E. Solid-state decompositions - stagnation or progress? Journal of Thermal Analysis and Calorimetry, 2000, vol. 60, pp. 863-877.

10. Vyazovkin S. Kinetic concepts of thermally stimulated reactions in solids: a view from a historical perspective. International Reviews in Physical Chemistry, 2000, vol. 19, pp. 4560 .

11. Prasad T.P., Kanungo S.B., Ray H.S. Non-isothermal kinetics: some merits and limitations. Thermochimica Acta, 1992, vol. 203, pp. 503-514.

12. Ninan K.N., Krishnan K., Krishnamurthy V.N. Kinetics and mechanism of thermal decomposition of insitu generated calcium carbonate. Journal of Thermal Analysis, 1991, vol. 37 , pp. 1533-1543.

13. Khawam A., Flanagan D.R. Solid-state kinetic models: basics and mathematical fundamentals. Journal of Physical Chemistry B, 2006, vol. 110, pp. 17315-17328.

14. Dollimore D., Tong P., Alexander K.S.The kinetic interpretation of the decomposition of calcium carbonate by use of relationships other than the Arrhenius equation. Thermochimica Acta, 1996, vol. 282-283, pp. 13-27.

15. Haixiang C., Naian L., Weitao Z. Critical study on the identification of reaction mechanism by the shape of TG/DTG curves. Solid State Sciences, 2010, vol. 12, pp. 455460. 